\title{
Interweaving Rubrics in Information Systems Program Assessments- Experiences from Action Research at Two Universities
}

\author{
Olga Petkova, Central \\ Connecticut State University, \\ New Britain, CT, USA
}

petkovao@ccsu.edu

\author{
Doncho Petkov, Eastern \\ Connecticut State University, \\ Willimantic, CT, USA
}

petkovd@easternct.edu

\section{Marianne J. D’Onofrio, Central Connecticut State University, New Britain, CT, USA}

\author{
donofrio@ccsu.edu
}

\begin{abstract}
This paper describes research experiences in student learning assessment in information systems programs. These research experiences resulted from research implemented at two Connecticut State universities during the past six years. The paper provides an overview of the expanding research in Information Systems education assessment and links assessment work at the program level with the use of standardized rubrics for projects or other artifacts. Additionally, the paper presents reflections on the authors' action research achievements in student learning assessment and gives some directions for future work.
\end{abstract}

Keywords: program assessment, action research, assessment, information systems education.

\section{Introduction}

Educational assessment is an important aspect in promoting improvement in student learning and greater accountability in higher education. Its role is emphasized also by accrediting organizations at professional and regional levels. According to Ewell (2002:9), assessment as a term refers to the processes used to determine an individual's mastery of complex activities, generally through observed performance. Various academic program assessment methods are discussed in Palomba and Banta (1999).

Over the last few years assessment has become a major topic in Information Systems (IS) educa-

Material published as part of this publication, either on-line or in print, is copyrighted by the Informing Science Institute. Permission to make digital or paper copy of part or all of these works for personal or classroom use is granted without fee provided that the copies are not made or distributed for profit or commercial advantage AND that copies 1) bear this notice in full and 2) give the full citation on the first page. It is permissible to abstract these works so long as credit is given. To copy in all other cases or to republish or to post on a server or to redistribute to lists requires specific permission and payment of a fee. Contact Publisher@ InformingScience.org to request redistribution permission. tion research. Earlier publications in IS program assessment had dealt predominantly with indirect methods of program assessment based on student surveys (Pick \& Kim, 2000; Williams \& Price, 2000). A well defined agenda using exams as direct assessment measures related to the IS2002 model curriculum (Gorgone et al., 2002) was initiated at the Center for Computing Education 
Interweaving Rubrics in Information Systems Program Assessments

Research (CCER) (Landry et al., 2006; McKell, Reynolds, Longenecker, Landry, \& Pardue, 2006; Reynolds, Longnecker, Landry, Pardue, \& Applegate, 2004). The first account of a comprehensive effort on assessment at the level of an IS program was presented at ISECON 2004 by Petkova and Jarmoszko (2004) and was later expanded in Petkova, Jarmoszko, and D'Onofrio (2006). A comprehensive theoretical review on how various learning outcomes can be promoted in an IS program is presented in Todorova and Mills (2004). Stemler and Chamblin (2005) provide an account on how a well designed assessment process played a role in the accreditation of a Management Information Systems (MIS) program at a small liberal arts university. They used a set of common rubrics for assessing student performance on various artifacts. Another illustrative case study on implementing program assessment using the standardized tests by CCER at a private university is presented in White and McCarthy (2007). Such an approach is rigorous as it is tied strongly to the standard curriculum for the IS discipline IS2002.

Several other research efforts relate to narrower aspects of assessment in IS education. For example, assessment at the course level in Systems Analysis is discussed in Hoopes (2000). Amoroso (2004) has explored the use of online tools for assessing student learning in large classes. O'Neil (2005) and Robinson and Thoms (2001) have also focused on assessment of computer literacy knowledge. The use of multi-year projects as an assessment instrument in an IS program is discussed in Cooper and Heinze (2007).

A growing use of portfolios as an assessment instrument in other academic disciplines indicates their potential for IS education. Akar (2001) presents experiences with the use of portfolios in assessment in education. Portfolios seem to be a well established assessment method in education but to the best of the authors' knowledge there are limited accounts of their use in an IS or CS program apart from Higgs and Sabin (2005). The latter paper reports on research about the design of systems supporting portfolios. Love and Cooper (2004) have explored the design criteria for information systems supporting assessment portfolios. Sweat-Guy and Buzetto-More (2007) provide an analysis of common e-portfolio features and existing platforms.

Projects are a typical artifact with a strong presence in IS education. If projects are to be evaluated using rubrics in assessing student learning, the rubrics must be rigorously designed. These rubrics need to be standardized in different courses across the program (Petkov \& Petkova, 2006). The use of unified rubrics in interrelated subjects is one way to address program level assessment. Projects from specific courses at important stages of the student studies within a program can be used as evidence of student progress with respect to the overall program goal (Petkov, Petkova, Jarmoszko,\& D’Onofrio, 2007).

The above analysis shows that the assessment research in the field of IS education is growing and is quite diverse. It also shows that there is a shift from indirect methods of assessment to the use of direct measures of student learning. Most of the published research (including among others Aasheim, Gowan, and Reichgelt (2007)) has been aimed towards the development of course level assessment that is aligned with overall program goals without inclusion of a portfolio. There is a disconnect between such program level assessment work and the use of portfolios in IS education. The latter provide a more holistic approach to assessment and, thus, provide the motivation for this research, which integrates and extends the authors previous work (Petkov \& Petkova, 2006; Petkov et al., 2007; Petkova et al., 2006). Its contribution is in linking the assessment of projects and other artifacts at the course level with portfolios and program level assessment. Such an approach may easily be adapted to the mission and needs of any program.

The purpose of this paper is to show how portfolios can be combined with course level assessment in an IS program and to provide some lessons from the action research that helped the authors develop their ideas. These lessons evolved from the authors' experience in implementing assessment in two IS programs in Connecticut. The paper continues with a discussion of assess- 
ment as action research. Next is a brief summary of the authors' work on program level assessment, on the development of standardized rubrics for projects, and on the relationship between program level assessment and project rubrics. The paper then concludes with some directions for future research.

\section{Framing Assessment Efforts as Action Research}

The approach to assessment in an IS program that Petkova and Jarmoszko (2004) and Petkova et al. (2006) pursued is different from previously published work in IS program assessment. They explored the integrated process of curriculum design, assessment and instruction, advocated by Heywood (2000, p. 64). Petkova and Jarmoszko (2004) and Petkova et al (2006) approached assessment in the spirit of action research (Baskerville \& Wood-Harper, 1998) since the latter is appropriate in this situation. Professors are affecting the process of curriculum design, assessment and instruction but at the same time they are affected by it. The authors entered this integrated process suggested by Heywood (2000) with some preconceived ideas about each of the activities involved. During the process the authors quickly discovered that the activities needed to be adapted to the evolving situation. Through this interactive process more was learned about how to design the curriculum of the program to better meet the needs of the students, how to adapt teaching methods to make student learning more effective, and how to assess student learning. The authors discovered that to integrate portfolios in the overall assessment of an IS program, adequate measures for assessing student achievement at the course level had to be developed. These measures can also be used for portfolio assessment.

The authors' research focus was mainly student learning assessment at the program level. The research began in 2002 with an analysis of the existing program assessment methodologies. Next, an exploration of the suitability of these methodologies for the discipline of Management Information Systems at Central Connecticut State University was undertaken. Then, a process for implementing assessment of the IS program was developed. (Petkova et al., 2006). A similar process began in 2006 at Eastern Connecticut State University, where the focus was initially (2004) at the course level and by mid 2006 moved to program level assessment.

The analysis of existing assessment approaches (Petkova \& Jarmoszko, 2004) shows that they differ primarily in the number and the sequencing of assessment steps. The assessment model that the authors used had four steps:

1. Setting goals and asking questions

2. Gathering of evidence

3. Interpreting

4. Using results

The above assessment model, followed throughout the Connecticut State University System, is a simple and flexible approach, integrating most of the steps found in other assessment models. It is a cyclical model, and each subsequent cycle is influenced by the learning that takes place in the previous steps.

A critical success factor in the implementation of the assessment model is the involvement of all faculty members in assessment activities. At both Central Connecticut State University and Eastern Connecticut State University, the learning curve has been steep and rewarding. Through the assessment process implementation, much has been learned about curriculum design, assessment, and instruction. The following sections briefly summarize the authors' experiences. 


\section{Reflections on the Process for IS Program Assessment}

The Department of Management Information Systems at CCSU decided in the spring of 2002 to conduct an exercise in assessing its undergraduate program. After discussion, it was decided to conduct a course-embedded assessment pilot via a fourth year MIS course, Systems Analysis and Design (SA\&D). Possible methods of assessment within the SA\&D setting were explored. The decision was made to employ a combination of simulation and performance appraisal through a set of standardized business cases used in semester-long group projects (Petkova and Jarmoszko, 2004). A pilot assessment was performed and the pilot results prompted some important curriculum changes. For example, a new course in Systems Implementation and Project Management was created, and course prerequisites throughout the entire MIS curriculum were reorganized.

By the fall of 2003 the Department faculty developed sufficient knowledge to continue the program assessment using a more structured and theoretical approach. The consensus in the department was that course-embedded assessment was not an appropriate method for conducting assessment of the entire MIS program. The decision was made to examine other approaches that might provide a comprehensive, holistic evaluation of different program aspects. An analysis and reformulation of the MIS program goals were undertaken, studying how these program goals matched various levels of Bloom's taxonomy of student learning (Bloom, 1956). Student learning outcomes were then formulated. Next, curriculum and syllabus analysis was conducted to map out the specific courses and learning activities that supported the program goals and learning outcomes. The department members identified four courses which covered most comprehensively all the educational goals listed above: MIS400 (Business Decision Analysis/ Knowledge Base Systems), MIS410 (Networks \& Telecommunications), MIS450 (Enterprise Strategies and Transformation) and MIS462 (Systems Implementation and Project Management).

Through the subsequent syllabus analysis, conducted by faculty teams teaching these courses, the duplication and fragmentation of some topics within the curriculum were eliminated. As a result of this work, the most important artifacts and activities to measure the learning outcomes were identified. These artifacts included but were not limited to projects, presentations, simulations and case studies.

The department decided that the artifacts created by the students in the four courses would be the input into the assessment process. These artifacts were to include but not be limited to:

- several reports on individual projects in knowledge management

- a report on an interactive simulation exercise in strategic decision making

- a group project report on decision support systems

- a group project report in network design

- a group project report and a completed and implemented information system (the final capstone experience)

The strengths and weaknesses in the student learning assessment that were identified after analyzing the collected data are reflected in Petkova and Jarmoszko (2004). Further reflections on the evolution of the assessment process within the MIS program at CCSU are presented in Petkova et al. (2006). Some major changes in the MIS curriculum resulted from the assessment process. A new course "Systems Implementation and Project Management" was created in order to assure that students are exposed to the best practices of Project Management. The two courses "Systems Analysis and Design" and "Database Management" were moved from fourth to third level courses in order to assure timely student exposure to important IS development concepts. This change made it possible for students completing these courses successfully to have the necessary 
background information and maturation period to be prepared for concepts discussed in their senior year courses.

The MIS program assessment at CCSU provided each professor with a significant learning experience and the opportunity to reflect on past assessment exercises and to plan for process improvement, which can lead to an improvement in student learning.

The MIS faculty reached consensus that the portfolio approach needed to be supplemented with behavioral observations and performance appraisal in order to create an effective assessment program.

While originally the long-term goal in the MIS program was to create a system for the developing web-based student portfolios in house, it has become clear that the development effort and maintenance costs are prohibitive. Thus, the goal has been modified to select a commercially available portfolio system that allows IT students to upload content, including their work and accomplishments. The authors will use a prototype system supporting student assessment developed by Petkova (2006) as their guide in selecting a commercial portfolio system. At this stage emerged some issues related to the need to provide a uniform standard for assessment within different courses. The artifacts in the four MIS courses chosen for assessment were evaluated by faculty committees consisting of at least two faculty members. Each committee was responsible for determining its own assessment methods. A unification of the scales was attempted but a standard structure for the criteria in the rubrics was not achieved. This leads to the important issue of standardized rubric development for assessment of student projects or other artifacts across the IS program. This work was started initially at Eastern Connecticut State University by the second author and later was expanded in cooperation with the first author of this paper.

\section{Lessons from the Development of Unified Project Rubrics in Different IS Courses and their Link to Program Level Assessment}

According to Heywood (2000, p. 329), a student is asked in an educational project to plan, specify, make, test and evaluate an artifact or an idea. A review of past research on project work is presented in Brown, Bull and Pendleburry (1997, pp. 121-122). According to Brown et al. (1997), projects provide good, all around ability testing, and potential for sampling a wide range of practical, analytical and interpersonal skills. Projects also provide a means of measuring project and time management skills, and team work skills and leadership. Brown et al. (1997) also suggest that an instructor may assess students' projects using: artifacts, reports, poster presentations/exhibitions, presentations; and/or log books. The selection of a particular method or set of methods will depend on the project's nature (Petkov \& Petkova, 2006). For example, in an introductory subject on IS fundamentals, typically the report is assessed; while in a systems analysis or a database class, it is the design (the artifact) of a specific system accomplished in a project that is assessed.

Rubrics tell potential performers what elements of performance matter most and how the work to be judged will be distinguished in terms of relative quality (Wiggins, 1998, p. 153). Scoring rubrics are descriptive scoring schemes that are developed by teachers or other evaluators to guide the analysis of student products or processes (Brookhart, 1999).

Petkov and Petkova (2006) analyzed the existing research on criteria used to evaluate projects (Heywood, 2000, p. 330; Brown et al, 1997; Wiggins, 1998). They demonstrated how the analysis of program goals can be linked to the existing knowledge on project evaluation criteria, deriving standardized criteria for project assessment across different courses in an IS program. Petkov and Petkova (2006) present examples of unified rubrics developed for project assessment in an intro- 
ductory IS course (Information Management) and in a Systems Analysis course. Table 1 shows how the general criteria for assessment of projects within an IS program can be converted into specific criteria and sub-criteria that reflect the nature of different courses.

The general project assessment criteria (Table 1, Column 1) were derived after mapping the IS program goals to the existing research on project evaluation criteria (Brown et al., 1997; Wiggins, 1998). One may note that the third and fourth criteria for Information Management and Systems Analysis and Design are similar since they are generic in nature. On the other hand, the first and second criteria are specific for each course reflecting its nature. The first criterion in the second column is specific to the technical skills covered in the introductory IS course at ECSU, while the first criterion in the third column is reflecting the technical skills relevant for the course on Systems Analysis and Design. In a similar way the second criterion for assessing projects is specific for each subject due to the differences in relevant methods applicable to them. To illustrate, the first two criteria corresponding to two of the most important learning outcomes for Systems Analysis and Design are presented here:

- Ability to define user requirements of an information system and to document the analysis and design of the system.

- Ability to apply methods and techniques for feasibility analysis, requirements analysis and Unified Modeling Language (UML) modeling in practice.

One may note that while the fourth criterion for Information Management relates to a project presentation, the respective criterion for Systems Analysis relates to a project walkthrough which is seen by the authors as more suitable for presenting and assessing a project in that discipline. This is another example of customization within the uniform structure of the rubrics across different courses depending on their nature. We note also that the sub-criteria are introduced to allow the evaluations along more dimensions and, thus, to improve the analytical power of the rubric.

Having a standard set of criteria contributes to faster diffusion of assessment in individual courses since it takes less time for instructors to develop a good grasp of what they want to measure in a course and how. Rubrics positively affect student performance as well. Petkov and Petkova (2006) have reported the results of an exploratory field experiment showing the positive impact of rubrics on student learning demonstrated through the improved quality of their projects.

The authors' experiences in using rubrics and in analyzing student projects qualitatively in several courses over four years demonstrate the usefulness of rubrics. Rubrics help the students focus their attention on the essential issues when working on projects. The average rating for all team projects along each criterion may serve as an indication for potential problem areas that need to be addressed by the instructor. The results could be used to derive measures for student learning improvement, to reach a balance between the four types of outcomes at the various levels of the IS program and to improve curriculum. Rubrics can support the standardization of project assessment methods in courses with several sections, a typical problem for introductory level classes which are usually of interest to those inspecting a program for accreditation purposes.

The adherence to the same number of criteria and sub-criteria organized in a uniform way is a precondition for comparison of student performance in different courses (Petkov et al., 2007). The comparison is based on a principle related to absolute measurement in a Multicriteria Decision Making approach called The Analytic Hierarchy Process (Saaty, 1990): a particular student project is not compared to another student project but instead it is assessed with respect to the ideal level of achievement for that criterion in the respective course. Thus, conclusions may be drawn about whether students in a particular course have scored better or worse than those in another course with respect to their technical proficiency or methodological proficiency or organization/documentation skills or presentation communication skills. 
Table 1: General project assessment criteria transformed into a uniform set of criteria relevant for two IS subjects: An introductory course on Information Management and a course on Systems Analysis and Design

(based partly on Petkov and Petkova, 2006)

\begin{tabular}{|c|c|c|}
\hline \multirow[t]{2}{*}{$\begin{array}{l}\text { General Project Assessment } \\
\text { Criteria }\end{array}$} & $\begin{array}{l}\text { BUS } 205 \text { Information Man- } \\
\text { agement }\end{array}$ & $\begin{array}{l}\text { BIS } 370 \text { Systems Analysis and } \\
\text { Design }\end{array}$ \\
\hline & Course Specific Criteria & Course Specific Criteria \\
\hline \multirow{4}{*}{$\begin{array}{l}\text { 1. Technical level of proficiency } \\
\text { demonstrated through applica- } \\
\text { tion of the technical knowledge } \\
\text { associated with the subject. }\end{array}$} & $\begin{array}{l}\text { 1. Ability to analyze a business } \\
\text { as a work system }\end{array}$ & $\begin{array}{l}\text { 1.Ability to define user re- } \\
\text { quirements of an information } \\
\text { system and to design a system }\end{array}$ \\
\hline & $\begin{array}{l}\text { 1.1.Correct application of the } \\
\text { work system model }\end{array}$ & $\begin{array}{l}\text { 1.1.Correct application of analy- } \\
\text { sis and design principles }\end{array}$ \\
\hline & 1.2.Appropriate data collection & $\begin{array}{l}\text { 1.2.Appropriate requirements } \\
\text { gathering }\end{array}$ \\
\hline & $\begin{array}{l}\text { 1.3. Are the conclusions in line } \\
\text { with the factors for success or } \\
\text { failure of IS }\end{array}$ & $\begin{array}{l}\text { 1.3. Is the final product relevant } \\
\text { for a practical implementation of } \\
\text { the information system }\end{array}$ \\
\hline \multirow{4}{*}{$\begin{array}{l}\text { 2.Problem solving methodologi- } \\
\text { cal skills and ability to organize } \\
\text { information, ability to compare } \\
\text { a problem situation against best } \\
\text { business practices or to select } \\
\text { and justify the best alternative } \\
\text { solution }\end{array}$} & $\begin{array}{l}\text { 2.Review of best business prac- } \\
\text { tices: }\end{array}$ & $\begin{array}{l}\text { 2.Ability to apply feasibility } \\
\text { analysis, requirements analysis } \\
\text { and UML modeling in practice: }\end{array}$ \\
\hline & $\begin{array}{l}\text { 2.1.To what extent is the review } \\
\text { relevant }\end{array}$ & $\begin{array}{l}\text { 2.1.How are requirements as- } \\
\text { sumptions relevant }\end{array}$ \\
\hline & $\begin{array}{l}\text { 2.2.Is there evidence of critical } \\
\text { appraisal of other work or is it } \\
\text { just descriptive }\end{array}$ & $\begin{array}{l}\text { 2.2.Is there evidence of applica- } \\
\text { tion of the analysis and design } \\
\text { principles }\end{array}$ \\
\hline & $\begin{array}{l}\text { 2.3.Is there a summary linking } \\
\text { the review to the problem on } \\
\text { hand }\end{array}$ & $\begin{array}{l}\text { 2.3.Is there evidence of applying } \\
\text { UML correctly in a system life } \\
\text { cycle model }\end{array}$ \\
\hline \multirow{4}{*}{$\begin{array}{l}\text { 3. Organizational, interpersonal } \\
\text { and time management skills } \\
\text { demonstrated in the execution } \\
\text { of the project and its recom- } \\
\text { mendations }\end{array}$} & $\begin{array}{l}\text { 3.Execution and Recommenda- } \\
\text { tions of the project }\end{array}$ & $\begin{array}{l}\text { 3.Execution and Recommenda- } \\
\text { tions of the project }\end{array}$ \\
\hline & $\begin{array}{l}\text { 3.1. Have the main points to } \\
\text { emerge from the project being } \\
\text { picked up for discussion? }\end{array}$ & $\begin{array}{l}\text { 3.1. Have the main points to } \\
\text { emerge from the project being } \\
\text { picked up for discussion? }\end{array}$ \\
\hline & $\begin{array}{l}\text { 3.2. Is there a consideration on } \\
\text { the resources needed for the sug- } \\
\text { gested transformation and the } \\
\text { schedule? }\end{array}$ & $\begin{array}{l}\text { 3.2.Is there a consideration on the } \\
\text { resources needed for the sug- } \\
\text { gested system and the schedule }\end{array}$ \\
\hline & $\begin{array}{l}\text { 3.3. Was the project developed } \\
\text { within the time allocated for the } \\
\text { tasks? }\end{array}$ & $\begin{array}{l}\text { 3.3. Was the project developed } \\
\text { within the time allocated for the } \\
\text { analysis and design phases? }\end{array}$ \\
\hline \multirow{5}{*}{$\begin{array}{l}\text { 4. Communication skills, dem- } \\
\text { onstrated through the organiza- } \\
\text { tion of the project and its pres- } \\
\text { entation }\end{array}$} & 4. Presentation & 4. Presentation \\
\hline & $\begin{array}{l}\text { 4.1.Clarity of explanation and } \\
\text { conclusions }\end{array}$ & $\begin{array}{l}\text { 4.1.Clarity of explanation and } \\
\text { conclusions }\end{array}$ \\
\hline & $\begin{array}{l}\text { 4.2.Visual impact of the presenta- } \\
\text { tion }\end{array}$ & $\begin{array}{l}\text { 4.2.Visual impact of the project } \\
\text { walk-through }\end{array}$ \\
\hline & $\begin{array}{l}\text { 4.3.Use of audio visual aids, body } \\
\text { language }\end{array}$ & $\begin{array}{l}\text { 4.3.Use of audio visual aids, body } \\
\text { language }\end{array}$ \\
\hline & 4.4. Response to questions & 4.4. Response to questions \\
\hline
\end{tabular}

The suggested standardized rubrics allow a uniform way of evaluating projects across particular subjects in an IS program that may be considered crucial in shaping the skills of IS graduates. The use of standardized rubrics across a program is a necessary component for the successful implementation of student portfolios. The approach can be used also to track the evolution of student 
Interweaving Rubrics in Information Systems Program Assessments

performance from one subject to another or over a number of years providing an alternative to the use of standardized tests like those developed by CCER. We may note that subjectivism cannot be completely eliminated in the assessment process but it can be controlled through the involvement of more experts in the assessment. Such an approach does not rely on the existence of one set of standard courses like IS2002 (Gorgone et al., 2002).

\section{Conclusion}

In this paper, the authors provide an overview of their work and of other research in IS program assessment, a topic of significant concern to IS educators since 2000. While Petkova et al. (2006) report the findings from two cycles of implementing program level assessment in the MIS department of CCSU, this paper reports on experiences through a third cycle. The third cycle involved the experimental implementation of an assessment system for student portfolios and lessons from that process. These lessons point to the need to balance benefits with costs in all assessment activities. Lessons from rubric development using a standardized structure in various courses were reported. The authors do not claim that their approach is better than tests; in fact, a weakness of their approach, the danger of subjectivism in the assessment of a particular artifact, is reported. Strengths of their approach include flexibility in adapting to program needs and the assessment of tangible student skills demonstrated through the completed project.

This paper reports how project assessment rubrics at course level assessment may be linked to overall program assessment and portfolio assessment. The standardized approach to designing rubrics in individual IS subjects (see Petkov \& Petkova, 2006) and its use in program assessment shown here lays the foundation for longitudinal assessment of student learning across different stages of an academic program, reflected through appropriate artifacts organized in student portfolios. Having a uniform structure of the project rubrics allows the measurement and comparison of student progress through their studies within the program. Then, educators can draw comparisons along similar indicators about student performance in different courses - something that cannot be achieved easily using standardized exams in different courses unless they are structured in several sections each measuring particular aspects of student learning. The authors are in the process of collecting such longitudinal data and believe this is a viable line for future research.

The paper provides a brief summary of the multifaceted assessment process of student learning at the program level developed at CCSU and evolving in somewhat similar form at ECSU. The efforts and costs associated with it were well rewarded by the learning that occurred and the results obtained in the last six years. The challenge is to sustain this process for the benefit of the students.

\section{References}

Aasheim, C., Gowan, J. A., \& Reichgelt, H. (2007). Establishing an assessment process for a computing program. Information Systems Education Journal (ISEDJ), 5(1).

Akar, H. (2001). Evaluating higher education learners through portfolio assessment. Proceedings of Informing Science Conference 2001.

Amoroso, D. (2004). Use of online assessment tools to enhance student performance in large classes. Proceedings of ISECON 2004.

Baskerville, R., \& Wood-Harper, T. (1998). Diversity in information systems action research methods. European Journal of Information Systems, 7(2), 90-107.

Bloom, B. S. (1956). Taxonomy of educational objectives: The classification of educational goals: Handbook I, cognitive domain. New York; Toronto: Longmans, Green.

Brown, G., Bull, J., \& Pendleburry, M. (1997). Assessing student learning in higher education. London and New York: Routledge. 
Brookhart, S. M. (1999). Teaching about communicating assessment results and grading. Educational Measurement: Issues and Practice, 18(1), 5-13.

Cooper, G., \& Heinze, A. (2007). Centralisation of assessment: Meeting the challenges of multi-year team projects in information systems education. Journal of Information Systems Education;18(3), 345-355.

Ewell, P.T. (2002). An emerging scholarship: A brief history of assessment. In T.W. Banta (Ed.), Building a scholarship of assessment. Jossey- Bass.

Gorgone, J. T., Davis, G. B., Valachich, J. S., Topi, H., Feinstein, D. L., \& Longenecker, H. E. (2002). IS'2002: Model curriculum and guidelines for undergraduate degree programs in information systems, Available at http://www.is2002.org

Heywood, J. (2000). Assessment in higher education: Student learning, teaching, programmes and institutions. Jessica Kingsley Publishers.

Higgs, B., \& Sabin, M. (2005). Towards using online portfolios in computing courses. Proceedings SIGITE 2005, 323-328.

Hoopes, J. E., \& Fisher, C. W. (2000). Assessment of a systems analysis methods course in a small liberal arts college. Proceedings ISECON 2000.

Landry, J., Pardue, H., Longenecker, H., Reynolds, J., McKell, L. \& White. B. (2006). Using the IS model curriculum and CCER exit assessment tools for course-level assessment. Information Systems Education Journal (ISEDJ), 4(73)

Love, T., \& Cooper, T. (2004). Designing online information systems for portfolio-based assessment: Design criteria and heuristics. Journal of Information Technology Education, 3, 65-81. Retrieved from http://jite.org/documents/Vol3/v3p065-081-127.pdf

McKell, L., Reynolds, J., Longenecker, H., Landry, J., \& Pardue, H. (2006). The Center for Computing Education Research (CCER): A nexus for IS institutional and individual assessment. Information Systems Education Journal (ISEDJ), 4(69).

O'Neil, T.D. (2005). The effective use of web-based training and assessment in a computer literacy course. Proceedings of ISECON 2005.

Palomba, C., \& Banta, T. (1999). Assessment essentials. Jossey-Bass.

Petkov, D., \& Petkova, O. (2006). Development of scoring rubrics for projects as an assessment tool across an IS program. Journal on Issues in Informing Science and Information Technology (IISIT), 3, 499509. Retrieved from http://informingscience.org/proceedings/InSITE2006/IISITPetk214.pdf

Petkov, D., Petkova, O, Jarmoszko A. \& D'Onofrio, M. (2007).Using scoring rubrics to assess student learning from projects in interrelated information systems courses. Proceedings of the pre-ICIS IAIM Conference, Montreal, December 2007.

Petkova, O \& Jarmoszko, T. (2004). Assessment loop for the MIS program at Central Connecticut State University: A practice of learning, reflection and sharing. ISECON 2004 Proceedings.

Petkova, O., Jarmoszko, T. A., \& D’Onofrio, M. J. (2006). Management Information Systems (MIS) program assessment: Toward establishing a foundation. Journal of Informatics Education Research $(J I E R), 8(2)$.

Pick, J. B., \& Kim, J. (2000). Program assessment in an undergraduate information systems program: Prospects for curricular and programmatic enhancement. Proceedings of the 15th Annual Conference of the IAIM, Brisbane, Australia, 2000.

Reynolds, J. H., Longnecker, H. E., Jr., Landry, J. P., Pardue, J. H., \& Applegate, B. (2004). Information systems national assessment update: The results of a beta test of a new information systems exit exam based on the IS 2002 model curriculum. Information Systems Education Journal, 2(24).

Robinson, L. H., \& Thoms, K. J. (2001). A longitudinal study of college student computer knowledge. The Journal of Computer Information Systems, 42(1), 9-12.

Saaty, T. (1990). Multicriteria decision making - The analytic hierarchy process (2nd ed.). Pittsburgh: RWS Publications. 
Interweaving Rubrics in Information Systems Program Assessments

Stemler, L., \& Chamblin, C. (2006). The role of assessment in accreditation: A case study for an IS department. Information Systems Education Journal (ISEDJ), 4(39).

Sweat-Guy, R., \& Buzzetto-More, N.A. (2007). A comparative analysis of common e-portfolio features and available platforms, The Journal of Issues in Informing Science and Information Technology, 4, 327-342. Retrieved from http://proceedings.informingscience.org/InSITE2007/IISITv4p327342Guy255.pdf

Todorova, N., \& Mills, A. (2004).Development of assessment portfolios for IS majors. Proceedings of ISECON 2004.

White, B., \& McCarthy, R. (2007). The development of a comprehensive assessment plan: One campus' experience. Proceedings of ISECON 2007.

Wiggins, G. (1998). Educative assessment. Designing assessments to inform and improve student performance. Jossey Bass.

Williams, S. R., \& Price, B. A. (2000). Strengths and weaknesses of an information systems program: A longitudinal assessment of student perceptions. Proceedings of the $15^{\text {th }}$ Annual IAIM Conference, Brisbane, Australia.

\section{Author Biographies}

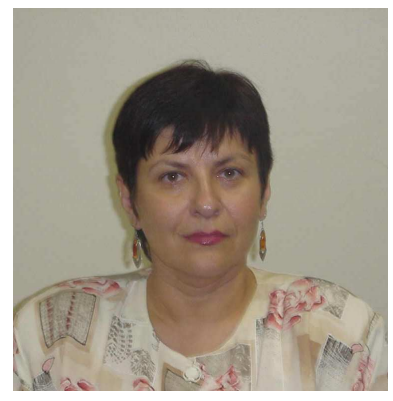

Dr Olga Petkova is a Full Professor in MIS at Central Connecticut State University, USA. Previously she has taught at several universities in South Africa and Zimbabwe and worked at the Bulgarian Academy of Sciences in Sofia. Her publications are in software development productivity, systems thinking and Information Systems education. They have appeared in Decision Support Systems, Journal of Information Technology Theory and Applications (JITTA), Journal of Informatics Education Research, JITCA and elsewhere.

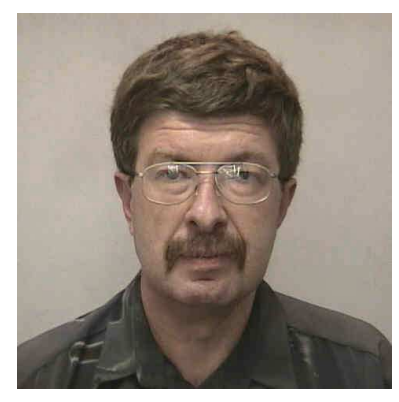

Dr. Doncho Petkov is a Full Professor and Coordinator of the BIS program at Eastern Connecticut State University, USA. He is a deputy editor (USA) for Systems Research and Behavioral Science and Senior Area Editor (Software Engineering) of IJITSA . His publications in IS management, systems thinking and Software Engineering have appeared in the Journal of Systems and Software, Decision Support Systems, Telecommunications Policy, IRMJ, International Journal on Technology Management, IJITSA, JITCA, South African Computing Journal and elsewhere.

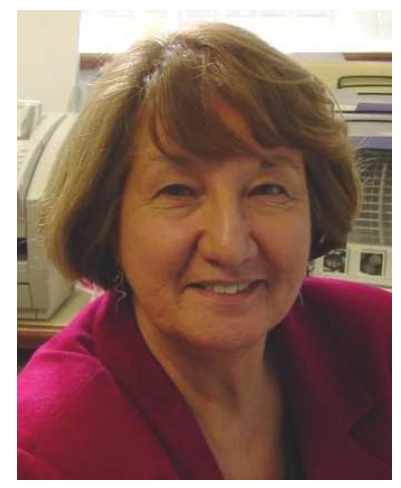

Dr. Marianne D'Onofrio is a Full Professor and Chair in MIS in the School of Business at Central Connecticut State University, USA. She earned her Ph.D. from The Ohio State University. Prior to CCSU, Dr. D'Onofrio was a professor at Utah State University, University of Wisconsin-Madison, and Indiana University. She is on the boards of several academic journals. Her research and teaching interests are in Group Support Systems, Decision Support Systems and MIS Management. 